\title{
Simultaneous impact of the different water supply and year type on processing tomato yield
}

\author{
Böcs, A. Pék, Z. \& Helyes, L. \\ Institute of Horticultural Technology, Szent István University, Páter K. út 1., H-2103 Gödöllö, Hungary
}

\begin{abstract}
Summary: A two year (2008 and 2009) open field experiment was conducted to study the effect of irrigation on the yield parameters and fruit components of processing tomato. Two different treatments were applied: regularly irrigated (RI), irrigation cut-off 30 days before harvest (CO), compared with unirrigated control (RF). The optimal water supply was calculated from average daily temperature. The aims of the study were to investigate the effect of different water supply on yield quantity. The regularly irrigated plant stands gave significantly higher yield, and unirrigated plants showed yield loss. Water supply had strong positive $\left(\mathrm{R}^{2}=0.81\right)$ effect on marketable yield and average fruit weight $\left(\mathrm{R}^{2}=0.78\right)$. Linear regression showed, that $46.5 \mathrm{~mm}$ more water supply caused $10 \mathrm{t} /$ ha more marketable yield, and $13.4 \mathrm{~mm}$ more water supply caused $1 \mathrm{~g}$ more in the average fruit weight. The irrigation increased the Brix yield as well.
\end{abstract}

Keywords: processing tomato, irrigation cut-off, yield

\section{Introduction}

The importance of tomato cultivation has been growing rapidly in the last decades in the world. Beside the fresh market tomatoes, the processing tomato has a great importance in the food industry, basically because of its health promoting features (Clinton, 1996, 1998; Giovannuсci, 1999). The processing tomato cultivation has changed a lot recently, the production areas were decreased, but the yield is getting higher. Processing tomato cultivation is only profitable in Hungary if the yield is over $45-55 \mathrm{t} / \mathrm{ha}$ (Fruitveb, 2008), but the optimal yield depends on element of growing technologies, like plant propagation, irrigation method and the use of hybrids (Helyes et al. 2006). Ecological conditions e.g. solar radiation, temperature and precipitation take a great effect on tomato yield (Helyes \& Varga, 1994, Helyes et al., 1999, Pék et al., 2008). It is possible to increase the yield to $90-110$ t/ha with an appropriate cultivation, under irrigated conditions.

This experiment was undertaken to investigate the effects of water supplement on fruit yield of drip-irrigated processing tomatoes. Among other factors, crop management, particularly water and nutrient supply, is of primary importance of quality and quantitative yield (Dumas et al., 1994). The colour (lycopene content) and Brix ${ }^{\circ}$ of processing tomato at harvest are an important quality criterion. The soluble solid content (Brix) of fruits was often very high without irrigation, this value decreased with irrigation. In spite of this the level of brix yield per hectar remarkably increased as a result of significantly higher yield quantity.

\section{Materials and method}

Tomato fruits were ensured from the test sites of Szent István University, Gödöllő, where various irrigation experiments of processing tomato were carried out (Cselötei and Varga, 1988; Varga, 1988).

The experiments were carried out in 2008 and 2009. The experimental field is brown forest soil, mechanical compositions are sand, sandy-clay. Water management shows similarity to sandy soils, thus characteristics are low water capacity and good hydraulic conductivity. In summer, the soil water capacity can provide sufficient water supply for the plants only for a short period of time. The subsoil water is below $5 \mathrm{~m}$, therefore it cannot influence the water turnover. Tomato cultivar (Brigade $\mathrm{F}_{1}$ ) was investigated in the present study.

In 2008, the area of the experiment was $300 \mathrm{~m}^{2}$ and the area of one plot was $25 \mathrm{~m}^{2}$. Seeds were sown on $7^{\text {th }}$ April 2008 in greenhouse and transplanted on $12^{\text {th }}$ May. Tomato seedlings were planted out in twin rows, $0.4 \mathrm{~m}$ spacing inside the raw and $1.2 \mathrm{~m}$ between adjacent twin rows, the space between the plants in the row was $0.3 \mathrm{~m}$. There were two treatments. Regularly irrigated plants (RI) which got $297 \mathrm{~mm}$ irrigation water and $144 \mathrm{~mm}$ precipitation (441 $\mathrm{mm}$ together) from the beginning of May, the other was the Cut Off substance $(\mathrm{CO})$ which means the irrigation was stopped at the beginning of the ripening process (got $369 \mathrm{~mm}$ water including precipitation); there was an unirrigated rainfed control (RF) as well which got $297 \mathrm{~mm}$ precipitation only. Crop density was 4,2 plant $/ \mathrm{m}^{2}$. 
Treatments: RI: $411 \mathrm{~mm}$

CO: $297 \mathrm{~mm}$

RF: $144 \mathrm{~mm}$

In 2009, the test field was $500 \mathrm{~m}^{2}$ and the area of one plot was $20 \mathrm{~m}^{2}$. Seeds were sown on $25^{\text {th }}$ March 2009 in greenhouse and transplanted on $5^{\text {th }}$ May. Tomato seedlings were planted out similarly last year. There were also two treatments: RI plants, which got $261 \mathrm{~mm}$ irrigation water (417 $\mathrm{mm}$ together with the $156 \mathrm{~mm}$ precipitation), CO substance got $140 \mathrm{~mm}$ irrigation water $(296 \mathrm{~mm}$ with precipitation) and RF stands got $156 \mathrm{~mm}$ precipitation. Crop density was 4.2 plant $/ \mathrm{m}^{2}$.

Treatments: RI: $417 \mathrm{~mm}$

CO: $296 \mathrm{~mm}$

$\mathrm{RF}: 156 \mathrm{~mm}$

Drip irrigation water was given out according to the air temperature (daily irrigation water $(\mathrm{mm})=$ average daily temperature $\times 0.2$ ). National Meteorological Institute forecasts were used to calculate with the probable daily air temperature.

Changes of the environmental factors were monitored via measuring three parameters. During the experiment we defined the air temperature $\left({ }^{\circ} \mathrm{C}\right)$, relative humidity $(\mathrm{RH} \%)$ and incoming light intensity $\left(\mu \mathrm{mol} \mathrm{m} \mathrm{m}^{-2} \mathrm{~s}^{-1}\right)$. Basic nutrition supply was given out when plants were transplanted with Agroblen 18-8-16 fertiliser, resulting $266 \mathrm{~kg} \mathrm{ha}^{-1} \mathrm{~K}_{2} \mathrm{O}$. Marketable (red and green) and diseased fruits were measured at harvesting on $12^{\text {th }}$ August 2008 and $17^{\text {th }}$ August 2009.

The Brix was examined with refractometer (AST 1230, Tokyo, Japan). All statistical analyses were performed using the Microsoft ${ }^{\circledR}$ Excel 2002 Analysis Toolpak (Microsoft Corporation Corporate Headquarters Redmond, USA).

The effect of irrigation on tomato yield depends on the actual weather conditions, basically the air temperature and precipitation (quantity and dispersion).

Figure 1. shows average daily temperatures and precipitations during the two year period.

\section{Results and discussion}

There were significant differences between the control and irrigated plant stands according to the water supply which was formulated the canopy values also. The regularly irrigated tomato plants' yield exceeded the unirrigated ones in each year. It is emerged from the study that the irrigation has a positive effect on the amount of the harvestable yield. Effect of irrigation (RI, CO) increased the marketable yield with $100 \%$ respectively in 2008 . In 2009 , according to the less precipitation, the treatments showed significantly higher differences.

Water supply had strong positive $\left(\mathrm{R}^{2}=0.85\right)$ effect on marketable yield and average fruit weight $\left(\mathrm{R}^{2}=0.89\right)$. Linear regression showed, that $46.5 \mathrm{~mm}$ more water supply caused $10 \mathrm{t} / \mathrm{ha}$ more marketable yield, and $13.4 \mathrm{~mm}$ more water supply caused $1 \mathrm{~g}$ more in the average fruit weight. We could

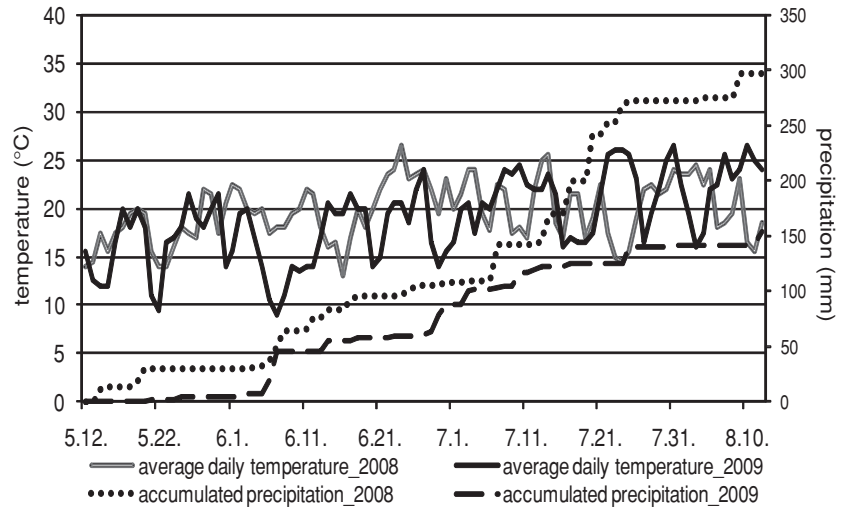

Figure1: Meteorological data during tomato vegetation period in 2008 and 2009.

establish strong positive $\left(\mathrm{R}^{2}=0.65\right)$ water supply effect on harvested number of fruits per hectare. These results are demonstrated in Figure 2. calculated from two years data.

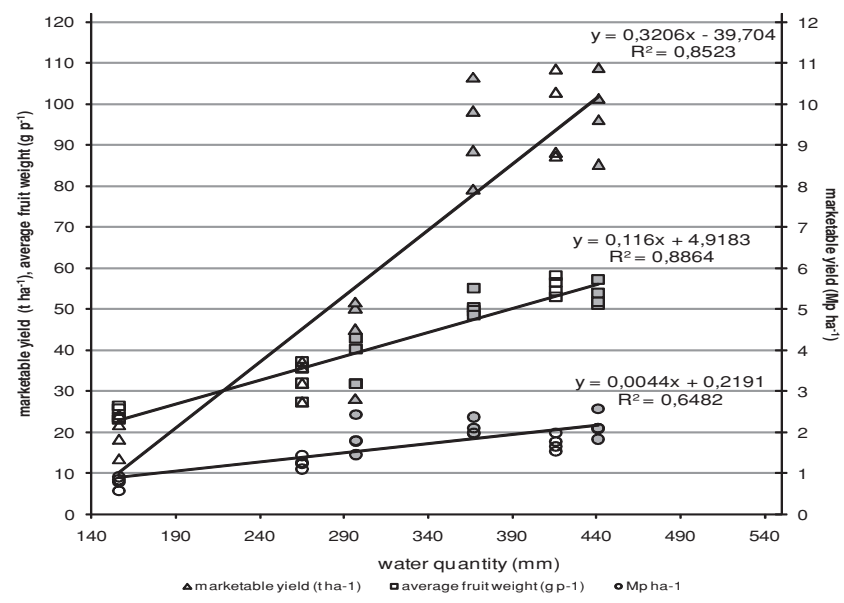

Figure 2: Correlation between water and total marketable yield, pieces and fruit weight of processing tomato in 2008 and 2009 (Brigade $\mathrm{F}_{1}$ ). The symbols show: $\square$ A: 2008 data, $\square \bigcirc \triangle$ : 2009 data.

Regular irrigation caused a significant decrease in the Brix $^{\circ}$ of individual tomato fruits, while it resulted in a significant increase of Brix yield per hectare (Table 1.)

Table 1: Average yield parameters of marketable tomato fruits

\begin{tabular}{|c|c|c|c|c|c|c|}
\hline & & $\begin{array}{c}\text { Average } \\
\text { fruit weight } \\
(\mathrm{g})\end{array}$ & Mp ha-1 & $\begin{array}{c}\text { Marketable } \\
\text { yield } \\
(\mathrm{t} \mathrm{ha-1})\end{array}$ & Brix $^{\circ}$ & $\begin{array}{c}\text { Brix yield } \\
\left(\mathrm{t} \mathrm{ha}^{-1}\right)\end{array}$ \\
\hline \multirow{3}{*}{2008} & $\mathrm{RF}$ & $36.8 \pm 5.6^{b}$ & $1.9 \pm 0.4^{\mathrm{c}}$ & $43.9 \pm 10.6^{b}$ & $5.5 \pm 0.2^{\mathrm{a}}$ & $2.4 \pm 0.6^{b}$ \\
\hline & $\mathrm{CO}$ & $53,6 \pm 2.7^{\mathrm{c}}$ & $2.2 \pm 0.3^{\mathrm{c}}$ & $101.9 \pm 1.9^{c}$ & & \\
\hline & RI & $51.9 \pm 1.7^{\mathrm{c}}$ & $2.2 \pm 0.3^{\mathrm{c}}$ & $98.0 \pm 9.7^{\mathrm{c}}$ & $6.5 \pm 0.2^{\mathrm{a}}$ & $5.4 \pm 0.7^{\mathrm{d}}$ \\
\hline \multirow{3}{*}{2009} & $\mathrm{RF}$ & $24.8 \pm 1.6^{\mathrm{a}}$ & $0.8 \pm 0.2^{\mathrm{a}}$ & $19.5 \pm 4.7^{\mathrm{a}}$ & $9.0 \pm 0.6^{\mathrm{d}}$ & $1.6 \pm 0.3^{a}$ \\
\hline & $\mathrm{CO}$ & $33.1 \pm 4.4^{\mathrm{b}}$ & $1.3 \pm 0.1^{\mathrm{b}}$ & $41.3 \pm 2.0^{\mathrm{b}}$ & $7.7 \pm 0.4^{\mathrm{c}}$ & $2.6 \pm 0.3^{b}$ \\
\hline & RI & $55.5 \pm 2.3^{c}$ & $1.7 \pm 0.2^{c}$ & $96.7 \pm 10.6^{\mathrm{c}}$ & $6.1 \pm 0.4^{b}$ & $3.7 \pm 0.8^{c}$ \\
\hline
\end{tabular}

Rainfed (RF) cut off (CO) regularly irrigated (RI). For each column bearing different superscript letter indicate significant differences according to Tukey's test. Values mean $\pm \mathrm{SD}$ 
Rainfed (RF) cut off (CO) regularly irrigated (RI). For each column bearing different superscript letter indicate significant differences according to Tukey's test. Values mean $\pm \mathrm{SD}$

\section{Conclusions}

Better water supply results higher yield and significantly reduces the soluble solids $\left(\mathrm{Brix}^{\circ}\right)$ of tomato fruit. However, the effect of irrigation to increase yield is stronger than the decreasing effect on Brix ${ }^{\circ}$. Therefore, the irrigation increases the Brix yield as well.

\section{Acknowledgement}

This study was partially funded by TECH-09-A3-20090230, USOK2009 project.

\section{References}

Clinton, S.K. (1998): Lycopene: Chemistry, biology and implications for human health and disease. Nutrition Reviews, 56: 35-51.

Clinton, S.K., Emenhiser, C. \& Schwartz, S.J. (1996): Cis-trans lycopene isomers, carotenoids, and retinal in the human prostate. Cancer Epidemiol Biomark Prev, 5: 823-833.
Cselötei, L. \& Varga, Gy. (1988): Probability and expected effects of tomato irrigation in Hungary. Acta Horticulturae, 220: 365-370.

Dumas, Y., Leoni, C., Portas, C.A.M. \& Biéche, B. (1994): Influence of water and nitrogen availability of processing tomato in the European Union countries. Acta Horticulturae, 376: 185-192.

Fruitveb (2008): A zöldség-gyümölcs ágazat helyzete Magyarországon, 9-10.

Giovannucci, E. (1999): Tomatoes, tomato-based products, lycopene and cancer: review of the epidemiologic literature. Journal of National Cancer Institute, 91: 317-331.

Helyes, L. \& Varga, Gy. (1994): Irrigation demand of tomato according to the results of three decades. Acta Horticulturae, 376: 323-328

Helyes, L.,Varga, Gy., Pék, Z. \& Dimény, J. (1999): The simultaneous effect of variety, irrigation and weather on tomato yield. Acta Horticulturae, 487: 499-505.

Helyes, L., Dimény, J., Pék, Z. \& Lugasi, A. (2006): Effect of the variety and growing methods as well as cultivation conditions on ingredient of tomato (Lycopersicon lycopersicum (L.) Karsten) fruit. Acta Horticulturae, 712: 511-516.

Pék, Z., Helyes, L., Dimény, J., Paksi, A. \& Bőcs, A. (2008): Effect of ecological conditions on tomato fruits colour and ingredients during the ripening process. Cereal Research Communications, 36: Suppl. 1. 519-522.

Varga, Gy. (1988): The effect of irrigation on the quality of processing tomato. Acta Horticulturae, 220: 359-363. 